\title{
1987 Alaska fieldwork, De Long Mountains, Brooks Range, Alaska
}

Krass, V.A., and Amoco Oil Co.

GMC DATA REPORT 460

This GMC data report from the Amoco Heritage collection has been made available through funding from the FY2018 USGS National Geological and Geophysical Data Preservation Program, Grant Number G18AP00054. This project report is presented in its original format and has not been reviewed for technical content or for conformity to the editorial standards of DGGS. It should not be used or cited as reviewed data.

2019

State of Alaska

Department of Natural Resources

Division of Geological \& Geophysical Surveys
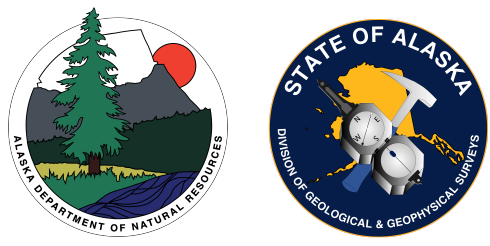


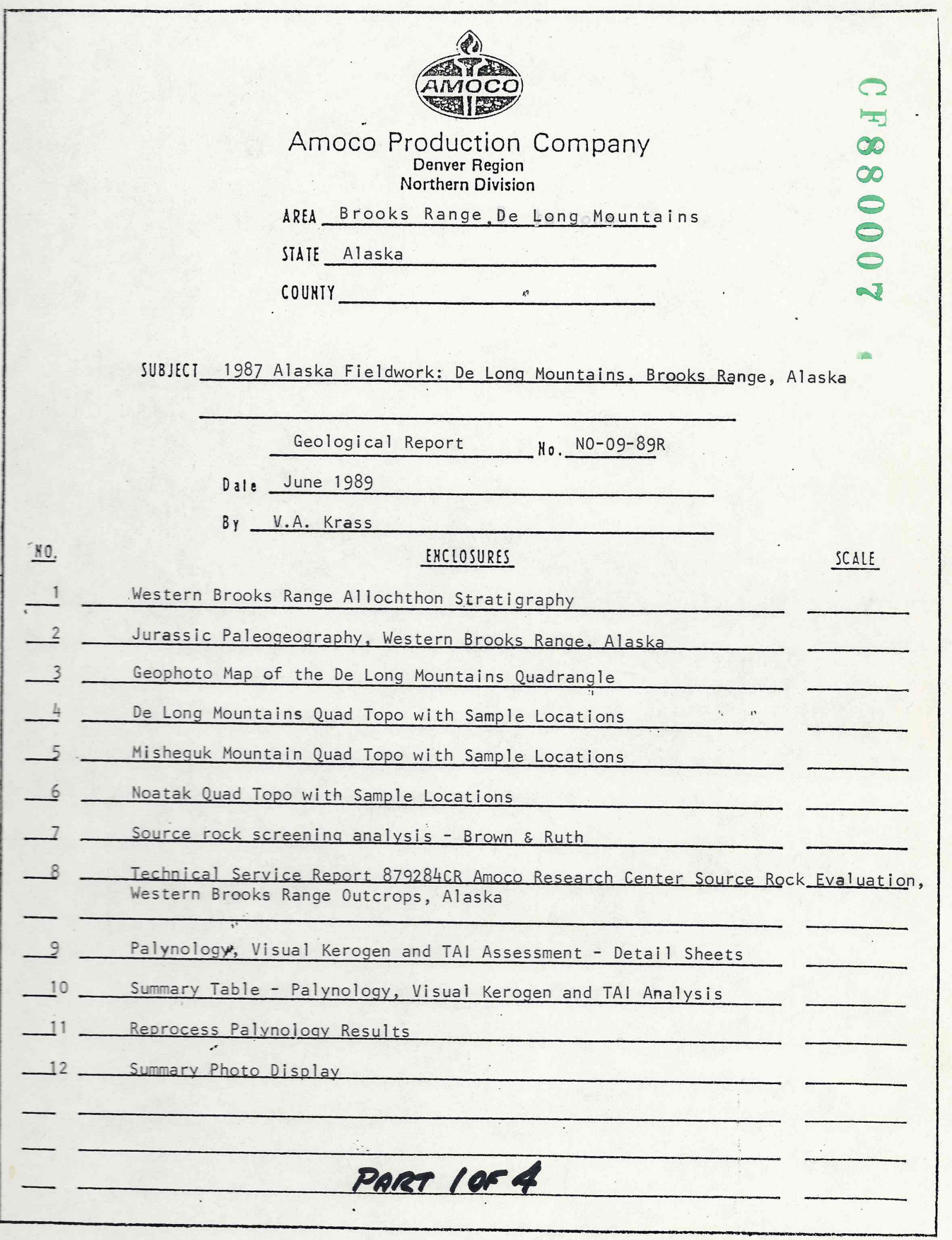


K. F. Arleth

$2002 \mathrm{AB}$

Denver Region, Northern Division Geological Report NO-09-89R, 1987 Alaska Fieldwork

De Long Mountains, Brooks Range

This report by Valerie Krass documents geological field work undertaken in 1987 in preparation for Chukchi OCS Sale 109. Results of this field work were incorporated into stratigraphic and geochemical models developed for the sale evaluation.

$$
\text { YER }
$$

A. E. Berman

Northern Division Geological Consultant

$\mathrm{AEB} / \mathrm{s} \operatorname{lm}$

CC: R. J. Shafer

Authorized for Transmittal:

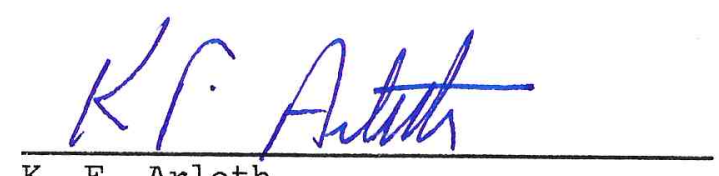

K. F. Arleth

Regional Geological Manager 
JUNE, 1989

\author{
Denver Region \\ Northern Division \\ Geological Report NO-09-89R \\ 1987 Alaska Fieldwork: \\ De Long Mountains, \\ Brooks Range, Alaska
}

INTRODUCTION

CONCLUSIONS

RECOMMENDATIONS

REFERENCES

ENCLOSURES

FIGURES

DISCUSSION

Regional Geologic Setting

Previous Work

1987 Field Work

Source Rock Analyses

Miss-Penn Kuna Formation

Permian-Jurassic Etivluk Group

Jurassic-Neocomian Ipewik Formation

Eariy Cretaceous Okpikruak

and Fortress Mountain Formations

Nuka Formation Study

Field Conditions and Logistical Support

\title{
APPENDICES :
}

I. Field Notes

II. Permit File

III. Sample Registers

IV. Photo Log

V. Government Report Compliance

VI. Helicopter Contract

VII. GCO Camp Contract

DITT. MISC. OPEN-FUE REFERENCES 


\section{INTRODUCTION}

This report documents the data collected and interpretations made during the 1987 Amoco field program in the De Long Mountains area of the western Brooks Range, North Slope, Alaska. The primary purpose of the field season was to evaluate the source rock potential of Jurassic to Pennsylvanian basinal facies for input into the OCS 109 and 97 Chukchi/Beaufort SUBSIDE program. A secondary objective was to examine the late Mississippian-Permian Nuka Formation and diabase sills, which have implications for a southern early Ellesmerian granitic source terrane and Miss-Penn rifting or strike-slip event.

Field work was conducted over a nine day period from July 20 to July 29, 1987. Amoco's field crew was led by Valerie Krass and assisted by Dave Muller, Ned Sterne and Margot Timble. The crew stayed in a mining camp in the western De Long Mountains, Lik Camp run by GCO Minerals, and was logistically supported by an ERA A-Star Helicopter (D. May, Pilot).

\section{CONCLUSIONS}

1. The distal basin facies of the upper Ellesmerian section (Triassic to Neocomian) contains good to excellent oil sources and has primary potential for generation of a significant volume of oil. The lower Ellesmerian section contains some oil-prone source rock facies (Kuna Fm, Siksikpuk $\mathrm{Fm}$ ), but is not thought to be volumetrically important to the Chukchi Sea from an oil generation standpoint. Results on source rock richness and kerogen type from these distal marine shales which outcrop in the western Brooks Range will help define and constrain the regional source model used as input for SUBSIDE for the OCS 109 and 97 lease sales.

2. Overall, the thermal maturity of the Ellesmerian source rocks in the western De Long Mountains is lower than that of the Lisburne Peninsula area (collected in 1986 field season; see Krass and Vait1). The De Long Mountains samples thus provide better information on kerogen type from pyrolysis convertibility data, elemental H/C ratios and FTIR data.

3. GCMS typing of the samples, run in order to correlate the oil source rocks with known North Slope oil types, was inconclusive. Most of the samples analyzed by TRC were deficient in biomarker compounds, making GCMS correlation impossible. Attempts to generate biomarkers via pyrolysis techniques also failed.

4. The Miss-Penn Kuna Formation, a marine shale facies equivalent to the Lisburne Group, is a good to excellent oil source with $1.5-6.0 \%$ TOC. The formation is thought to be too aerially restricted to be a volumetrically important hydrocarbon source for the Chukchi and western Beaufort Seas.

5. The Triassic-Jurassic Otuk Formation of the Etivluk Group is equivalent to the Shublik and lower Kingak Formations, and is an excellent oil source (TOC range $2.0-32.7 \%$ TOC), with good (Type II) to excellent (Type I) convertibilities. The rich Mesozoic oil sources (Shublik and Kingak) which fed the supergiant accumulation at Prudhoe Bay, continue to be excellent, volumetrically important oil sources in the western North Slope/ Chukchi Sea area.

6. The late Jurassic to early Cretaceous Ipewik Formation is equivalent to the upper Kingak and Pebble Shale Formations, and is a marginal to good oil source (0.9-1.4\% TOC). Some samples collected in the 1986 season show parts of the formation range to excellent source ( $11 \%$ TOC). Kerogen typing of this unit as oil prone shows that somewhere beneath the NPRA the upper Kingak/ Pebble Shale change source facies from proximal gas-prone in the 


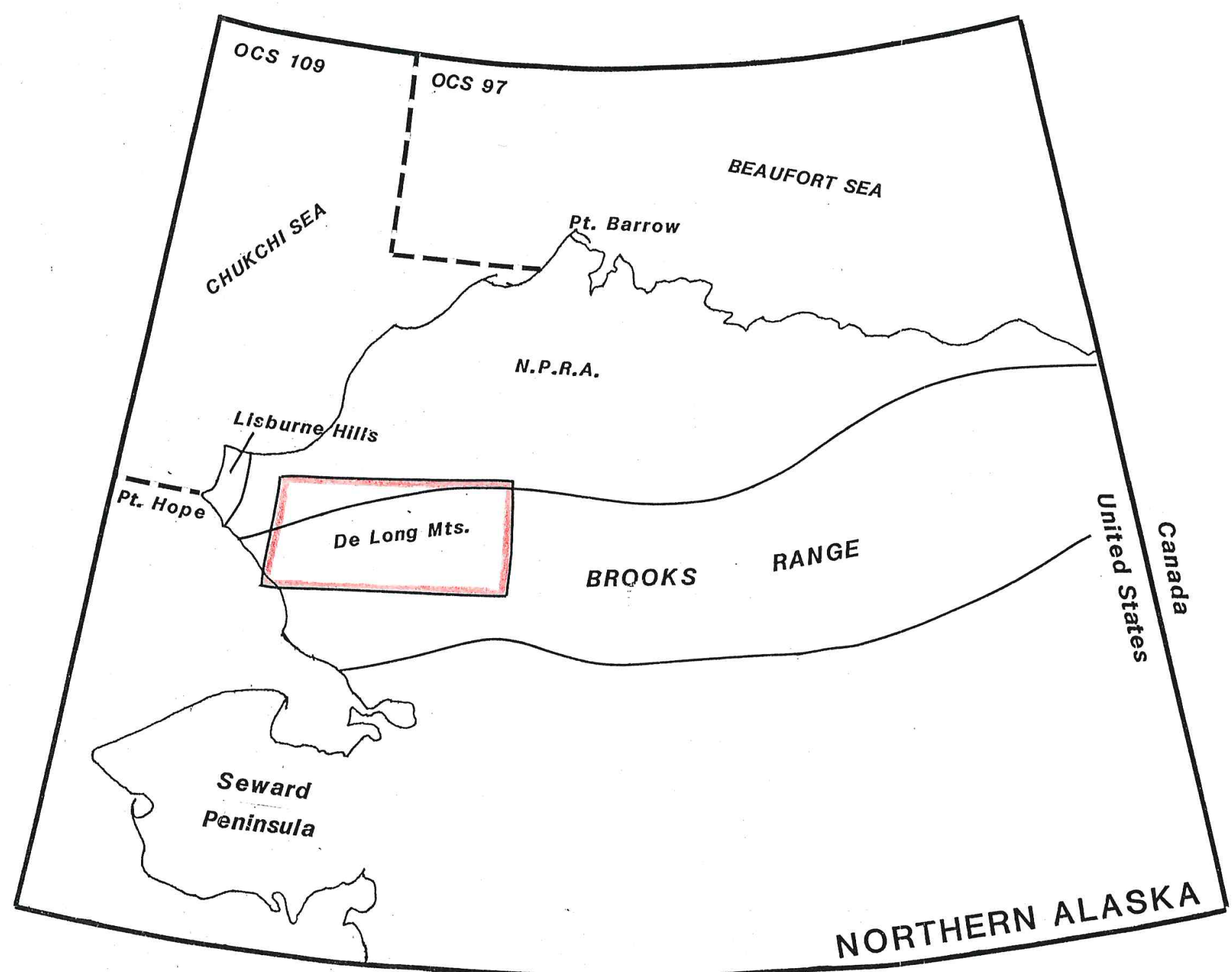

FIGURE 1: Index map of northern Alaska showing 1987 field work area in red. 
Barrow area to distal oil-prone in the outcrop belt. Overa11, this unit is a less rich source than the Otuk, and should have been a secondary oil source in terms of volumetrics for the Chukchi Sea area.

7. A minor number of analyses made on early Cretaceous turbidite facies confirm past work showing these units to be good sources (1.8-10.1\% TOC) with mixed gas and oil type kerogen.

8. Reconnaissance work confirmed the presence of the coarse-grained Nuka Arkose in two locations (Nuka Ridge and the coastal Asikpak River area) some 150 miles apart. The depositional and tectonic implications of this atypical unit remain enigmatic, but the presence of a coarse-grained clastic reservoir unit close to the Chukchi Sea provides upside reservoir potential for the early Ellesmerian section.

\section{RECOMMENDATIONS}

1. Source rock richness (TOC) and kerogen type data from this study, as well as additional data from the 1986 season, should be incorporated into a regional source rock basin model for the western North Slope. This work will serve as a primary input for regional SUBSIDE modelling in support of OCS 109 and 97.

2. If additional fieldwork is done in the De Long Mountains at a future date, additional source rocks should be collected in an attempt to get samples which contain sufficient biomarkers for source rock/oil GCMS correlation.

\section{REFERENCES}

Curtis, S.M., Ellersieck, I., Mayfield, C.F., and Tailleur, I.L., 1982, Reconnaissance Geologic Map of Southwestern Misheguk Mountain Quadrangle, Alaska: USGS Open-File Report 82-611.

Curtis, S.M., Ellersieck, I., Mayfield, C.V., and Tailleur, I.L., 1983, Reconnaissance Geologic Map of the De Long Mountains A1, B1, and Part of C1 Quadrangles, Alaska: USGS Open-File Report 83-185.

De Benedetti, J.J., Rose, R. and Abrahamson, E.W., 1971, Semidetailed Reconnaissance of the Western Brooks Range, Northern Alaska: Amoco Denver Geological Report No. CF710035.

Ellersieck, I., Curtis, S.M., Mayfield, C.F. and Tailleur, I.L., 1982, Reconnaissance Geologic Map of South-centra1 Mishequk Mountain Quadrangle, Alaska: USGS Open-File Report 82-612.

Ellersieck, I., Curtis, S.M., Mayfield, C.F. and Tailleur, I.L., 1983, Reconnaissance Geologic Map of the De Long Mountains A2, B2, and Part of C2 Quadrangles, Alaska: USGS Open-File Report 83-184.

Krass, V.A. and Vait1, J.D., 1986, 1986 Alaska Field Work: Lisburne Peninsula and Western De Long Mountains: Amoco Denver Vault Report No. CF860147.

Mayfield, C.F., Curtis, S.M., Ellersieck, I. and Tailleur, I.L., 1982, Reconnaissance Geologic Map of the Southeastern Part of the Misheguk Mountain Quadrangle, Alaska: USGS Open-File Report 82-613.

Mayfield, C.F., Curtis, S.M., Ellersieck, I. and Tailleur, I.L., 1983, Reconnaissance Geologic Map of the De Long Mountains A3, B3, and Parts of A4, B4 Quadrangles, Alaska: USGS Open-File Report 83-183. 
Mayfield, C.F., Tailleur, I.L., and Ellersieck, I., 1983, Stratigraphy, Structure and Palinspastic Synthesis of the Western Brooks Range, Northwestern Alaska: USGS Open-File Report 83-779.

Sable, E.G., Dutro, J.T. Jr., Mangus, M.D., and Morris, R.H., 1981, Geology of the Kukpowruk-Nuka Rivers Region, Northwestern Alaska: USGS Open-File Report 81-1078.

Tailleur, I.L., Mamet, B.L., and Dutro, J.T. Jr., 1973, Revised Age and Structural Interpretations of Nuka Formation at Nuka Ridge, Northwestern Alaska: AAPG Bu11., v. 57, no. 7, pp. 1348-1352.

\title{
ENCLOSURES
}

1. Western Brooks Range Allochthon Stratigraphy

2. Jurassic Paleogeography, Western Brooks Range, Alaska

3. Geophoto Map of the De Long Mountains Quadrangle

4. De Long Mountains Quad Topo with Sample Locations 1:250,000

5. Misheguk Mountain Quad Topo with Sample Locations 1:250,000

6. Noatak Quad Topo with Sample Locations 1:250,000

7. Source rock screening analyses - Brown and Ruth

8. Technical Service Report 879284CR Amoco Research Center Source Rock Evaluation, Western Brooks Range Outcrops, Alaska

9. Palynology, Visual Kerogen and TAI Assessment - Detail Sheets

10. Summary Table - Palynology, Visual Kerogen and TAI Analyses

11. Reprocess Palynology Results

12. Summary Photo Display

\section{FIGURES}

1. Index Map of Northern Alaska showing field location.

\author{
DISCUSSION
}

\section{REGIONAL GEOLOGIC SETTING}

The De Long Mountains lie in the western portion of the Brooks Range Province of the North Slope of Alaska (Figure 1). This part of the Brooks Range is underlain by a thick sequence of structurally disturbed rocks which range in age from Devonian to early Cretaceous. The section can be divided into two regional depositional packages:

The Ellesmerian Sequence is a thick section of carbonate and clastic rocks which were deposited in a stable continental margin setting from late Devonian to late Jurassic/early Cretaceous time. Rocks in this group include the Devonian Baird Limestone Group, Devonian to early Mississippian Endicott non-marine to marginal marine clastics, Mississippian to Pennsylvanian Lisburne platform carbonates and deeper water shales, and Permo-Triassic and Jurassic distal marine shales and cherts. Sediment input for the E1lesmerian section was dominantly from the north in Permian to early Cretaceous time. Prior to this time, a southern sediment source may have contributed to deposition of the Endicott Group and Nuka Formation (Miss-Perm clastic unit).

Pervasive diabase dikes and sills in the Lisburne section suggest that 
the hypothesized southern source terrane may have been removed by an extensional tectonic event (such as rifting or extensional strike-slip faulting) in Pennsylvanian-early Permian time.

The Brookian Orogeny, which began in the late Jurassic, created a rising sediment source in the south and resulted in deposition of the Brookian Sequence. A thick turbidite section (Okpikruak, Ogotoruk, Telavirak, Kisimolok, Fortress Mountain formations), later succeeded by deltaic clastics (the Nanushuk and Colville Groups), was deposited across the Brooks Range and northward into the growing foredeep of the Colville Trough. The compressional deformation associated with the Brookian Orogeny juxtaposed these rocks into a series of stacked thrust sheets which were later gently folded and eroded to form numerous klippen and fensters (see Enclosure 1, Western Brooks Range Allochthon Stratigraphy). Thus, the Ellesmerian continental margin sediments presently exposed in the western Brooks Range are allochthonous with respect to the North Slope, and represent facies originally deposited further to the south (see Enclosure 2, Jurassic Paleogeography). The Lisburne Peninsula and De Long Mountains are thought to belong to the structurally lowest thrust plate and have, therefore, moved the least with respect to the authochthonous Ellesmerian section which underlies the Chukchi Sea and NPRA. The dominant structural grain of the western Brooks Range thrusts documents south to north compression, with total shortening estimated at more than $800 \mathrm{~km}$ (Mayfield and others, 1983).

\section{PREVIOUS WORK}

Previous work for the western Brooks Range area is summarized in the Amoco 1986 Lisburne Peninsula/Western Brooks Range Field Work Report (Krass and Vaitl, CF860147). The 1986 field party collected source rock, reservoir rock and facies information to support regional geological interpretations being made for evaluation of the Chukchi/Beaufort OCS Sales 109 and 97. The text for this report includes a discussion of the stratigraphy of the Lisburne Peninsula and De Long Mountains area, and the stratigraphic correlations between the outcrop nomenclature and that typically used for the Barrow Arch area of the North Slope. The 1986 field survey concluded that additional source rock sampling in the De Long Mountains was warranted for the 1987 field season, to collect less thermally mature samples than the dominantly overmature source rocks collected in the Lisburne Peninsula area.

\section{FIELD WORK}

\section{Source Rock Analyses}

Brown and Ruth Labs (Englewood, Colorado) analyzed sixty-one potential source rock samples for Total Organic Carbon (TOC). Al1 samples with a TOC of 0.5 percent or higher were also run for Rock Eval Pyrolysis. Over 54 percent of the rocks analyzed contained greater than 1.0 percent TOC and are considered fair to excellent source rocks. The maximum TOC level ranged into the 22-35 percent leve1. Tmax data shows that most of the samples are in the early/late peak oil to peak gas maturity stage, with a small amount of samples in the past-peak gas to advanced maturity stage. The 33 samples with greater than $1.0 \%$ TOC were sent to Tulsa Research for more in-depth source rock analysis. Table I summarizes the samples analyzed and the results obtained from Brown and Ruth Labs (see Enclosure 7 for detailed Brown and Ruth report). Visual kerogen results are taken from Amoco Denver palynology study (D. Wall, Enclosures 9, 10). Table II summarizes the samples analyzed by Tulsa Research (see Enclosure 8 for complete Tech Service Report). 
TABLE I: SOURCE ROCK SUMMARY (BROWN AND RUTH SCREENING)

\begin{tabular}{|c|c|c|c|}
\hline Age/Fm & No. of Samples & TOC & Visual Kerogen \\
\hline Miss-Penn. Kuna & 7 & $0.98-8.41$ & $\begin{array}{l}\text { Woody, herbaceous } \\
\text { to amorphous }\end{array}$ \\
\hline $\begin{array}{l}\text { Perm-Jurassic } \\
\text { Etivluk Group }\end{array}$ & 3 & $0.37-22.14$ & $\begin{array}{l}\text { Woody, herbaceous } \\
\text { to amorphous }\end{array}$ \\
\hline Permian Siksikpuk & 3 & $0.15-1.41$ & $\begin{array}{l}\text { Woody to } \\
\text { amorphous }\end{array}$ \\
\hline $\begin{array}{l}\text { Triassic-Jurassic } \\
\text { Otuk Formation }\end{array}$ & 24 & $0.15-35.34$ & $\begin{array}{l}\text { Woody, herbaceous } \\
\text { to amorphous }\end{array}$ \\
\hline $\begin{array}{l}\text { Late Jurassic to } \\
\text { Early Cretaceous } \\
\text { Ipewik Formation }\end{array}$ & 18 & $0.18-1.73$ & $\begin{array}{l}\text { Woody, herbaceous } \\
\text { to amorphous }\end{array}$ \\
\hline $\begin{array}{l}\text { Ear1y Cretaceous } \\
\text { Okpikruak Formation }\end{array}$ & 5 & $0.35-1.75$ & $\begin{array}{l}\text { Woody, herbaceous } \\
\text { to amorphous }\end{array}$ \\
\hline $\begin{array}{l}\text { Early Cretaceous } \\
\text { Fortress Mountain }\end{array}$ & $1(?)$ & 10.55 & $\begin{array}{l}\text { Woody plus poss. } \\
\text { alt. amorphous }\end{array}$ \\
\hline
\end{tabular}

(Note: Formation identification based on palynology data and USGS field mapping. Structural complexity of area, along with similarity of basin facies of different ages, however, lends some uncertainty to identifications). 
TABLE II: SOURCE ROCK SUMMARY (TULSA RESEARCH DETAIL)

\begin{tabular}{|c|c|c|c|}
\hline Age/Fm & No. of Samples & TOC & Gen.Type/Maturity \\
\hline Miss-Penn. Kuna & 6 & $0.6-6.0$ & OIL / PPO-ADV \\
\hline $\begin{array}{l}\text { Perm-Jurassic } \\
\text { Etivluk }\end{array}$ & 5 & $1.5-26.3$ & OIL / EO-PG \\
\hline Permian Siksikpuk & 1 & 1.7 & $? \quad / \mathrm{ADV}$ \\
\hline $\begin{array}{l}\text { Triassic-Jurassic } \\
\text { Otuk Formation }\end{array}$ & 9 & $2.0-32.7$ & OIL / EO-PG \\
\hline $\begin{array}{l}\text { Jurassic-E. Cret. } \\
\text { Ipewik Formation }\end{array}$ & 9 & $0.9-1.4$ & OIL / EO-LPO \\
\hline $\begin{array}{l}\text { E. Cretaceous } \\
\text { Okpikruak }\end{array}$ & 2 & $0.8-1.8$ & $?$ / PPO-ADV \\
\hline $\begin{array}{l}\text { E. Cretaceous } \\
\text { Fortress Mtn. }\end{array}$ & 1 & 10.1 & GAS-OIL/PPO-PG \\
\hline
\end{tabular}

(Note: The above data incorporates palynological age control, which was not available to Tulsa Research at the time of their Tech Service Report). 
Miss-Penn Kuna Formation: The Kuna Formation is a deep water black shale facies equivalent in age to the lower-to-middle portion of the Lisburne Group as dated on the Arctic Platform to the north. Five of the six samples of Kuna Shale analyzed by the TRC were good (1.5\% TOC) to excellent (2.4-6.0\% TOC) oil sources. Thermal maturity of the samples was generally Past Peak 0il to Peak Gas, with one sample in the Advanced range. Regional mapping by the USGS in the western De Long Mountains suggests that the Kuna Formation was deposited in fault-bounded restricted sub-basins, where water depths were too great for carbonate deposition. Although an excellent oil source, the Kuna Formation is thought to be too aerially restricted to provide a volumetrically important source of hydrocarbons for the western Beaufort and Chukchi Seas. Although similar fault-bounded topography has been mapped in the Chukchi Sea area for Miss-Penn time, these sub-basins were more proximal, and may have filled with gas-rich non-marine to marginal marine shales and sandstones.

Permian-Jurassic Etivluk Group: The Permian to Jurassic Etivluk Group consists of interbedded, thick chert and siliceous to non-siliceous shale, and represents the dista1, deep water equivalents of the Sadlerochit Group, and Shublik, Sag River and lower Kingak formations. A11 of the datable samples from this group were interpreted as Triassic to Jurassic Otuk Formation, primarily equivalent to the proven source intervals of the North Slope Shublik/lower Kingak.

A total of 15 Etivluk Group samples were analyzed by the TRC. Of these, 9 were dated as Otuk Formation by USGS field mapping or palynology analysis, and rated as excellent oil sources with 2.0-32.7 $\%$ TOC. Most samples ranged between 2.0-8.2\% TOC, contained Type II oil kerogen and ranged from Early Peak Oil to Peak Gas thermal maturity. The one extremely rich sample (32.7\% TOC) contained Type I kerogen, with extremely rich convertibilities. An additional 5 samples, which were identified only as Etivluk Group, analyzed as good (1.5\% TOC) to excellent (2.1-26.3\% TOC) oil sources in the Early Peak Oil to Peak Gas range. Once again, the richest sample (26.3\% TOC) contained Type I kerogen with excellent convertibility. The one sample with a field age of Permian (Siksikpuk Formation) had 1.7\% TOC, with unknown generation type due to advanced thermal maturity.

Overa11, the Triassic to Jurassic Otuk portion of the Etivluk Group which outcrops in the western De Long Mountains contains extremely rich oil sources. This data shows that the rich Mesozoic source rocks (Shublik, Kingak) which generated oil for the supergiant accumulation at Prudhoe Bay Field, continue to be excellent, volumetrically significant oil sources in the western North Slope and Chukchi Sea areas.

Late Jurassic to Early Cretaceous Ipewik Formation: The late Jurassic to early Cretaceous Ipewik Formation, equivalent to the upper Kingak and Pebble Shale formations, was sampled at several locations along the Ipewik River, including an extensive outcropping at Horseshoe Bend, the type locality for the formation. The 9 soft, black shale samples run by the TRC consistently analyzed as marginal to good oil sources (0.9-1.4\% TOC) in the Early to Peak $0 i 1$ range. This data shows that the Pebble Shale changes kerogen type somewhere beneath the Colville Trough in the NPRA, from a gas source in the Barrow area to an oil source in the De Long Mountains. This unit, however, is a less rich oil source than the Otuk (Shublik/lower Kingak), and should have been a secondary oil source in terms of volumetrics for the Chukchi Sea prospects.

Early Cretaceous Okpikruak and Fortress Mtn. Formations: The Neocomian Okpikruak and Fortress Mountain Formations are part of the thick, turbidite sequence which was shed northward off the rising ancestral Brooks Range. Where previously analyzed in the NPRA, this group of rocks is dominated by gas and mixed gas-oil kerogen, with 
primary potential to generate gas. Two Okpikruak Formation samples were run by TRC and analyzed as marginal to good sources $(0.8-1.8 \%$ TOC) with unknown generation type due to Late Gas to Advanced thermal maturity. The one (?) Fortress Mountain sample analyzed was an excellent (10.1\% TOC) mixed gas-oil source at Past Peak 0il to Peak Gas. Palynology study of this sample was indeterminate, and it is assigned to the Fortress Mountain Formation tenuously, on the bas is of USGS mapping alone. Although this one sample has potential for some liquid generation, overall the Brookian turbidite facies is still considered to be dominantly a gas-prone facies.

\section{Nuka Formation Study}

The Nuka Formation consists of a $1000^{\prime}+$ thick section of clean, we11sorted arkosic sandstone and conglomeratic sandstone of Mississippian and Permian age (Tailleur, Mamet and Dutro, 1973). To date, the formation has been recognized in two locations in the western Brooks Range - in the Nuka Ridge area (Misheguk Mountain Quad, T9S-R31,32W) and some 150 miles to the west in the Asikpak River area near the coast (Noatak Quad, T29,30N-R26W). Both of these locations were visited briefly by the 1987 field crew to verify their existence (esp. the coastal location, which is shown on some USGS sketch maps but not discussed in the literature to any extent), and collect some reservoir samples. Although the coastal location is difficult to find due to its recessive outcrop pattern, the Nuka arkosic sandstone and conglomerate does indeed exist there and is 1ithologically identical in handsample to the type Nuka Ridge section rocks.

The existence of a coarse-grained arkosic formation of Miss-Permian age in the western Brooks Range is enigmatic. It indicates that a major granitic terrane (possibly over 150 miles in overall length) was locally eroding into a relatively high energy marine environment at a time when other portions of the area were receiving Lisburne carbonate deposition. It has been speculated that from late Devonian to early Permian time, the North Slope was joined to another continental plate to the south, with marine facies being deposited into a intervening seaway. This plate configuration is hypothesized to be the result of late Devonian Orogeny which may have included major granitic plutonism. In Penn-Permian time, the southern terrane was tectonically removed via rifting or extensional strike-slip tectonics. Evidence for this tectonic event includes the presence of major diabase dikes and sills within the Lisburne carbonates of the western Brooks Range (see Photo Log) and the change in facies to deeper water quiet chert and shale deposition for the Permian-Jurassic section. This tectonic event thus created a Atlantic-style margin for the southern part of the North Slope plate for the rest of Ellesmerian time (Permian-Jurassic), allowing deposition of major rich oil sources in the distal marine shale facies.

The history of the Nuka Formation, including its paleogeographic relationship to the rocks deposited in the Chukchi Sea, largely remains a mystery. The Nuka outcrops in structurally complex, remnant thrust sheets, and its original extent may never be known. However, if this unit does tie in some way to the western Ellesmerian sediment source terrane in the Chukchi Sea (the Chukchi Platform), it provides additional encouragement for good to excellent reservoir facies in units atypical of North Slope production.

(Note: Due to sale priorites, a reservoir study on the Nuka Formation outcrop samples and slides was not made. The samples are archived in the Amoco warehouse for future study).

\section{Field Conditions and Logistics}

While working in the De Long Mountains area, the Amoco field crew stayed at Lik Mining Camp, owned by GCO (Anchorage). The camp was clean and very comfortable by North Slope standards, and convenient to the area of interest. Due to its location within the heart of the 
range, fog and bear traffic were sometimes a problem. The Red Dog Mining Camp was not an option for the 1987 field season due to major construction crews building the mining road to facilitate opening the mine up to production. Once open as a producing mine, it is doubtful that it would be available for field lodging in the future. Other field crews in the area (Shell, Exxon) used a small commercial camp farther to the south on the Noatak (?) River. Although this location had much less fog problems, it is far less comfortable, less clean and less convenient to the northern range front, and is not recommended.

Transportation from Kotzebue to Lik Camp was made via small charter aircraft. As the western Brooks Range is often fogged in, being delayed in Kotzebue or in camp for several days is a possibility that must be planned for. While in the field, an ERA A-Star Helicopter was used. The A-Star is strongly recommended over a Jet Ranger if

long-distances (such as towards the coast or out to Nuka Ridge) are to be covered. 